SJ Quinney College of Law, University of Utah Utah Law Digital Commons

Utah Law Faculty Scholarship

Utah Law Scholarship

$10-2017$

\title{
The CAA Motor Vehicle Inspection and Maintenance Program: Is it Cost Effective?
}

Arnold W. Reitze Jr.

S.J. Quinney College of Law, University of Utah

Follow this and additional works at: http://dc.law.utah.edu/scholarship

Part of the Environmental Law Commons

\section{Recommended Citation}

Retize, A., The CAA Motor Vehicle Inspection and Maintenance Program: Is it Cost Effective? 47 ELR 10877 (2017)

This Article is brought to you for free and open access by the Utah Law Scholarship at Utah Law Digital Commons. It has been accepted for inclusion in Utah Law Faculty Scholarship by an authorized administrator of Utah Law Digital Commons. For more information, please contact valeri.craigle@law.utah.edu. 


\section{The CAA Motor Vehicle Inspection and Maintenance Program: Is It Cost Effective?}

\author{
by Arnold W. Reitze Jr.
}

Arnold W. Reitze Jr. is a Professor of Law at the S.J. Quinney College of Law at the University of Utah and a member of the Utah Air Quality Board.

\section{Summary}

Under the Clean Air Act, state-run vehicle inspection and maintenance $(\mathrm{I} / \mathrm{M})$ programs aim at preventing both manufacturers and consumers from circumventing or tampering with emissions control technology. Recent manufacturer cheating scandals, however, were detected by means other than I/M programs, and much I/M enforcement has been targeted at relatively low-level offenses. This Article traces the evolution of the I/M program and examines whether it currently provides benefits greater than its costs to vehicle owners, using Utah's Wasatch Front (which includes Salt Lake City) to illustrate how the program operates in practice. It concludes that there is little current information to support or reject the efficacy of the I/M program, and that a fresh look is warranted to improve its effectiveness.
$\mathrm{F}$ or nearly half a century, the Clean Air Act (CAA) has included a program to require new motor vehicles to meet federal emission standards. ${ }^{1}$ The federal government preempts the regulation of new motor vehicle emissions, but states regulate vehicle emissions after title passes to the consumer. This often includes an inspection and maintenance $(\mathrm{I} / \mathrm{M})$ program. The I/M program expanded significantly after 1977 because of the need for more stringent controls on emission sources in areas that were not achieving air quality goals.

$\mathrm{I} / \mathrm{M}$ is used to assure that vehicles continue to meet applicable emission standards after title passes to a consumer. In addition, I/M was needed because both the automotive industry and vehicle owners were motivated to circumvent the emissions control technology used to meet federal motor vehicle emissions standards. Both manufacturers and consumers were tampering with or removing air pollution control devices.

Over the years, the CAA and its implementing regulations evolved to further reduce motor vehicle emissions, which has included strengthening the I/M program. This has resulted in the development of vehicles with more effective and more complex emission control technology. The I/M program also evolved to produce a more sophisticated inspection process. However, the I/M program has failed to be an effective tool for preventing manufacturers from cheating on the CAA's motor vehicle emission control requirements. ${ }^{2}$

This Article traces the evolution of the I/M program and examines whether the current I/M program provides benefits greater than its costs in terms of both money and time to vehicle owners. Because the I/M program is implemented by state and local governments, Utah's Wasatch Front is used to illustrate how the program operates. Salt Lake City, located in Wasatch Front, is ranked by the American Lung Association as the seventh most-polluted U.S. city for short-term particulate pollution. ${ }^{3}$

Author's Note: Research assistance was provided by J.D. candidate Angeline Portel. This research was supported by the Albert and Elaine Borchard Fund for Faculty Excellence. The author wishes to thank Joe Thomas, Program Manager, and Richard McKeague III, Air Quality Modeler, Utah Division of Air Quality, as well as Timothy Russ and Kyle Olson of the U.S. Environmental Protection Agency's Region 8 for their assistance. All opinions are solely the view of the author.

1. 42 U.S.C. $\$ 7521$; ELR STAT. CAA \$202.

2. See Arnold W. Reitze Jr., The Volkswagen Air Pollution Emissions Litigation, 46 ELR 10564 (2016).

3. Press Release, American Lung Association, "State of the Air" Report Finds Continued Improvement in Air Quality, Yet Increase in Life-Threatening Spikes of Particle Pollution (Apr. 19. 2017). 


\section{History of the I/M Program}

The Motor Vehicle Air Pollution Control Act of 1965 authorized federal regulation of automotive emissions. ${ }^{4}$ In 1966, the U.S. Department of Health, Education, and Welfare established federal emission standards that first applied to model year (MY) 1968 vehicles. Subsequently, the Air Quality Act of $1967^{5}$ provided for federal preemption of new motor vehicle emissions controls, although California was eligible for a waiver so that it could set morestringent standards. ${ }^{6}$ It also established a program that provided grants for states to use to develop vehicle inspection programs. ${ }^{7}$ An important feature of the 1967 Act was its provision that it did not "preclude or deny to any State or political subdivision thereof the right otherwise to control, regulate, or restrict the use, operation, or movement of registered or licensed motor vehicles."

The CAA Amendments of 1970 gave the Administrator of the recently created U.S. Environmental Protection Agency (EPA) expanded authority to prescribe emission standards for new motor vehicles, but continued the 1967 authority for states to regulate motor vehicle emissions after the initial registration. ${ }^{9}$ Although the states could have developed I/M programs, few did. ${ }^{10}$ It was not until the enactment of the 1977 CAA Amendments that I/M became a required program for many states. ${ }^{11}$ The CAA Amendments of 1977 established December 31, 1982, as the deadline for states to meet national ambient air quality standards (NAAQS). ${ }^{12}$ The deadline could be extended until December 31, 1987, for violators of the carbon monoxide $(\mathrm{CO})$ or ozone $\left(\mathrm{O}_{3}\right)$ NAAQS if specified emission control measures were adopted. ${ }^{13}$ This included a mandate to establish an I/M program in nonattainment areas. ${ }^{14}$

EPA issued an I/M policy guidance document in 1978, but it never issued binding regulations. ${ }^{15}$ This resulted in considerable variation in state programs. The I/M program was resisted by most states, and EPA was slow to sanction states that failed to meet the I/M requirements. ${ }^{16}$ To

4. Pub. L. No. 89-272, 79 Stat. 992.

5. Pub. L. No. 90-148, \$\$103-104, 81 Stat. 485, 486-88.

6. Id. $\$ 208$ (CAA $\$ 209$, 42 U.S.C. $\$ 7543(\mathrm{a})$ ); see also City of Chicago v. General Motors Corp., 467 F.2d 1262, 1264, 2 ELR 20636 (7th Cir. 1972) (holding that the Air Quality Act of 1967 "explicitly provided for preemption”); see generally David P. Currie, Motor Vehicle Air Pollution: State Authority and Federal Preemption, 68 Mich. L. Rev. 1083, 1090 (1970).

7. Pub. L. No. 90-148, \$\$104, 210, and 209.

8. Id. $\$ 208(\mathrm{c})$.

9. Pub. L. No. 91-604, \$\$202 \& 209(c).

10. Prior to $1974, \mathrm{I} / \mathrm{M}$ programs were in operation in New York (for taxi cabs); Chicago, Illinois; Riverside, California; Cincinnati, Norwood, and Hamilton County, Ohio; Portland, Oregon; and Phoenix and Tucson, Arizona. National Academy of Sciences, Report by the Committee on Motor Vehicle Emissions 132-33 (1974).

11. CAA $\$ \$ 110(\mathrm{a})(2)(\mathrm{G}), 172(\mathrm{a})(2)(\mathrm{C}), 42$ U.S.C. $\$ \$ 7410(\mathrm{a})(2)(\mathrm{G}), 7502(\mathrm{a})$ (2) (C).

12. Pub. L. No. 95-95, \$129, 91 Stat. 685 (codified at 42 U.S.C. $\$ 7502$ ).

13. CAA $\$ \$ 110(\mathrm{a})(2)(\mathrm{G}), 172,42$ U.S.C. $\$ \$ 7410(\mathrm{a})(2)(\mathrm{G}), 7502$.

14. CAA $\$ 172(\mathrm{~b})(11)(\mathrm{B}), 42$ U.S.C. $\$ 7502(\mathrm{~b})(11)(\mathrm{B})$.

15. Inspection/Maintenance Program Requirement, 57 Fed. Reg. 52950, 52952 (Nov. 5, 1992).

16. See Arnold W. Reitze Jr. \& Barry Needleman, Control of Air Pollution From Mobile Sources Through Inspection and Maintenance Programs, 30 Harv. J. ON LEGIS. 409 (1993). obtain the cooperation of the states, EPA approved emission reduction credits for I/M programs that helped states obtain the emissions reductions for $\mathrm{CO}$ and $\mathrm{O}_{3}$ that are needed to obtain EPA's approval of a state implementation plan (SIP). ${ }^{17}$ EPA also provided grants to appropriate state agencies in amounts up to two-thirds of the cost of developing an I/M program. ${ }^{18}$

The 1977 I/M programs were only partially effective, for several reasons. First, vehicle emissions were tested when the engine was idling and at high idle (2,500 revolutions per minute), but not at the engine speed of a vehicle operating at highway speed. The idle mode test is easy to perform and requires minimal technical training. To pass this test, hydrocarbon ( $\mathrm{HC}$ ) and $\mathrm{CO}$ emissions must meet EPA's standards for the vehicle's MY. ${ }^{19}$ Second, vehicles were visually inspected for tampering, but the most common tampering involved using less-expensive leaded gasoline. ${ }^{20}$ The use of leaded gasoline destroys the effectiveness of the catalytic converter, which results in increased emissions, but the I/M test may not detect this tampering. ${ }^{21}$ Eventually, the CAA prohibited lead additives in gasoline. ${ }^{22}$ Finally, another weakness of the I/M program is that failed vehicles may not be repaired if the repair cost exceeds the regulatory cap that limits the cost imposed by the I/M program. ${ }^{23}$

The 1990 CAA Amendments imposed many new requirements on states with nonattainment areas. ${ }^{24}$ Ozone nonattainment areas were classified into five categories (marginal, moderate, serious, severe, or extreme) based on the severity of the nonattainment problem. ${ }^{25}$ New requirements were placed on marginal areas, with additional requirements for areas with lower air quality classifications. ${ }^{26}$

Ozone nonattainment areas are required to at least have a basic I/M program. ${ }^{27}$ Urbanized "serious" or worse nonattainment areas with a 1980 population of 200,000 or more must have an enhanced I/M program. ${ }^{28}$ States within the $\mathrm{O}_{3}$ transport region, which includes 11 northeastern states and the District of Columbia, must have enhanced I/M programs for their metropolitan statistical areas or areas with a 1990 population of 100,000 or more regardless of the area's classification. ${ }^{29} \mathrm{CO}$ nonattainment areas are divided into moderate and serious categories. ${ }^{30}$ Moderate areas are required to have a basic

17. Id. at 418 .

18. CAA $\$ 110,42$ U.S.C. $\$ 7410$

19. CAA $\$ 202(\mathrm{~g}), 42$ U.S.C. $\$ 7521(\mathrm{~g})$.

20. See generally Arnold W. Reitze Jr., Controlling Automotive Air Pollution Through Inspection and Maintenance Programs, 47 Geo. WASH. L. Rev. 705 (1979).

21. See generally Arnold W. Reitze Jr., The Regulation of Fuels and Fuel Additives Under Section 211 of the Clean Air Act, 29 Tulsa L.J. 485 (1994).

22. CAA $\$ 211(\mathrm{~g}) \&(\mathrm{k}), 42$ U.S.C. $\$ 7544(\mathrm{~g}) \&(\mathrm{k})$.

23. 40 C.F.R. $\$ 51.380(\mathrm{a})(6) \&(7)(2017)$.

24. Pub. L. No. 101-549, 104 Stat. 2399.

25. CAA $\$ 181,42$ U.S.C. $\$ 7511$.

26. CAA $\$ 182,42$ U.S.C. $\$ 7511$ a.

27. CAA $\$ 182(\mathrm{a})(2)(B), 42$ U.S.C. $\$ 7511 \mathrm{a}(\mathrm{a})(2)(\mathrm{B})$.

28. CAA $\$ 182(\mathrm{c})(3), 42$ U.S.C. $\$ 7511 \mathrm{a}(\mathrm{c})(3)$

29. CAA $\$ 184,42$ U.S.C. $\$ 7511 \mathrm{c}$.

30. CAA $\$ 186(a)(1), 42$ U.S.C. $\$ 7512(a)(1)$. 
I/M program, but nonattainment areas with an air quality design value greater than 12.7 parts per million at the time of classification are required to have an enhanced I/M program. ${ }^{31}$ In August 1990, 96 urban areas were in violation of $\mathrm{NAAQS}$ for $\mathrm{O}_{3}$ and 41 areas could not attain the CO standard. ${ }^{32}$

In response to the 1990 CAA Amendments, EPA upgraded the basic I/M requirements to provide new minimum standards concerning inspection frequency and test methods, as well as other improvements to the quality of the measurements. ${ }^{33}$ The upgraded I/M program is similar to the 1977 program, but is based on updated information, and the emission reduction benefits are estimated using the current version of EPA's mobile source emission model. ${ }^{34}$ An idle test is used to determine whether a vehicle's exhaust emissions meet standards specified in 40 C.F.R. Part 85, Subpart W. ${ }^{35}$ Nitrogen oxide $\left(\mathrm{NO}_{\mathrm{x}}\right)$ emissions must not increase because of steps taken to meet $\mathrm{HC}$ and $\mathrm{CO}$ requirements unless it is shown that $\mathrm{NO}_{\mathrm{x}}$ reductions will not improve air quality in the $\mathrm{O}_{3}$ nonattainment area. ${ }^{36}$ For MY 2001 and later, the basic program requires lightduty vehicles (LDVs) with an on-board diagnostic (OBD) system to be inspected, and any malfunctions identified by the system must be repaired. ${ }^{37}$ EPA estimates that $60 \%$ of the total tailpipe $\mathrm{HC}$ emissions from LDVs are caused by $20 \%$ of the vehicles that have serious emission control system malfunctions or degradation. ${ }^{38}$

The states with serious or worse $\mathrm{O}_{3}$ nonattainment areas were required to submit an enhanced I/M program by November 15, 1992. ${ }^{39}$ The statute specifies the seven elements required for an enhanced I/M program: (1) the use of computerized emission analyzers, including onroad testing devices; (2) no waivers for vehicles or parts covered by performance warranties, with limited exceptions; (3) the maximum repair costs a vehicle owner is required to expend must be increased to $\$ 450$ for repairs, adjusted annually based on the consumer price index; (4) enforcement through denial of vehicle registration, unless the state can demonstrate a more-effective enforcement program; (5) annual inspections, unless the state shows biennial inspections are as effective; (6) a centralized program, unless the state can demonstrate a decentralized program is as effective; and (7) a program for inspection of emission control diagnostic systems and the repair of identified malfunctions. ${ }^{40}$

31. CAA $\$ 187(a)(4) \&(6), 42$ U.S.C. $\$ 7512(a)(4) \&(6)$. The design value is the second highest eight-hour CO value evaluated over a two-year period.

32. Control of Air Pollution From New Motor Vehicles and New Motor Vehicle Engines; Regulations Requiring On-Board Diagnostic Systems on 1994 and Later Model Year Light-Duty Vehicles and Light-Duty Trucks, 56 Fed. Reg. 48272, 48273 (proposed Sept. 24, 1991).

33. 40 C.F.R. $\$ \$ 51.352-.358(2017)$

34. Id. $\$ 51.352(\mathrm{a})(2016)$.

35. Id.

36. Id. $\$ 51.352(\mathrm{~b})(2016)$.

37. Id. $\$ 51.352(\mathrm{c})(2016)$.

38. Id.

39. Id.

40. CAA $\$ 182(\mathrm{c})(3)(C), 42$ U.S.C. $\$ 7511 \mathrm{a}(\mathrm{c})(3)(\mathrm{C})$.
EPA promulgated more-specific requirements for the enhanced I/M program in its regulations, ${ }^{41}$ including $\mathrm{NO}_{\mathrm{x}}$ and volatile organic compound (VOC) performance standards in $\mathrm{O}_{3}$ nonattainment areas. ${ }^{42}$ The standards are based on the MY of the vehicle. ${ }^{43}$ Enhanced I/M requires testing under load during cycles of acceleration and deceleration, which is called the transient loaded, high-tech, or I/ M240 exhaust test. ${ }^{44}$ Because it simulates actual driving conditions, the loaded mode test provides a better indication of actual emissions than does the idle mode test. The regulations also require monitoring the effectiveness of the vapor recovery and recirculation mechanisms installed on vehicles built after 1971 using an evaporative system integrity test (pressure test) and an evaporative performance test (purge test). ${ }^{45}$ Enhanced I/M also requires the OBD system to be inspected and malfunctions repaired. ${ }^{46}$ States are required to deny motor vehicle registration if a vehicle fails the enhanced I/M test. ${ }^{47}$ However, an alternative enforcement mechanism may be used by a state if it is more effective than registration denial. ${ }^{48}$

Following enactment of the 1990 CAA Amendments, there was considerable resistance to implementing the I/M program by some states. ${ }^{49}$ A significant controversy involved EPA's insistence on the adoption of centralized I/M programs that were required by the statute unless the state demonstrated a decentralized program was equally effective..$^{50}$ A centralized enhanced I/M program was unpopular with most states because it forced vehicle owners to search for a limited number of centralized testing facilities. In addition, if testing and repairs could not be completed at the same facility, vehicle owners could be subject to a "ping-pong effect" by being forced to travel from a testing facility to a separate repair station and then return to the testing facility to ensure that the repairs corrected the emissions control problems. ${ }^{51}$ Moreover, a centralized system forced existing test stations to discontinue testing, which resulted in their loss of testing revenue as well as the income generated by related repair work..$^{52}$

In November 1994, the mid-term national elections created a Republican majority in Congress, ${ }^{53}$ which led to EPA proposing a rule to allow the states to have more

41. Inspection and Maintenance Program Requirements, 57 Fed. Reg. 31050 (1992) (codified at 40 C.F.R. \$51.351).

42. 40 C.F.R. $\$ 51.351(\mathrm{f})(2016)$.

43. Id. $\$ 51.351(\mathrm{f})(7)$.

44. Id. $\$ 51.351(\mathrm{f})(6)$.

45. Id. $\$ 51.357(\mathrm{~b})(3)$.

46. Id. $\$ 51.351(\mathrm{c})(2016)$.

47. Id. $\$ 51.361$.

48. Id.

49. See generally Arnold W. Reitze Jr., Federalism and the Inspection and Maintenance Program Under the Clean Air Act, 27 PAC. L.J. 1461, 1500 (1996) [hereinafter Federalism and the Inspection and Maintenance Program]. 50. CAA $\$ 182(\mathrm{c})(3)(\mathrm{C})(\mathrm{vi}) ; 42$ U.S.C. $\$ 7511 \mathrm{a}(\mathrm{c})(3)(\mathrm{C})(\mathrm{vi})$.

51. Federalism and the Inspection and Maintenance Program, supra note 49, at 1502.

52. Id.

53. See Arnold W. Reitze Jr., Air Quality Protection Using State Implementation Plans-Thirty-Seven Years of Increasing Complexity, 15 VILL. EnvTL. L.J. 209, 272 (2004); Federalism and the Inspection and Maintenance Program, supra note 49 , at 1511 . 
flexibility in addressing the I/M program requirements..$^{54}$ A rule change was finalized on September 18, 1995, 55 which addressed many of the concerns of the states administering the enhanced I/M program. ${ }^{56}$ Among the provisions of the flexibility rule was a change in the frequency of testing, allowing it to be done every other year. In addition, there was a provision allowing the required testing to be performed at a decentralized test-and-repair facility even though EPA continued to believe centralized inspections were more effective. ${ }^{57}$ A $50 \%$ reduction in emissions credits was imposed on states using the combined test-and-repair facilities, despite heavy opposition to this penalty. ${ }^{58}$ The 1995 flexibility rule also created a low enhanced I/M performance standard, which was easier to perform and less costly than the enhanced $\mathrm{I} / \mathrm{M}$ performance standard that was required in more seriously polluted areas. ${ }^{59}$

The conflict between EPA and the states was addressed on November 28, 1995, when President Bill Clinton signed into law the National Highway System Designation Act. ${ }^{60}$ Its $\$ 348$ made two significant changes to the I/M program. First, EPA:

shall not require adoption or implementation by a State of a test-only I/M240 enhanced vehicle inspection and maintenance program as a means of compliance with section 182 or 187 of the Clean Air Act ..., but the Administrator may approve such a program if a State chooses to adopt the program. ${ }^{61}$

Second, the "Administrator shall not disapprove or apply an automatic discount to a state implementation plan revision ... because . . . such plan revision is a decentralized or a test-and-repair program." ${ }^{62}$ Finally, EPA is to grant full interim approval to plans that show "a good-faith effort" to meet CAA requirements. ${ }^{63}$

On January 9, 1998, EPA removed the requirement that states use I/M240 technology, which allowed less-expensive testing technology to be used. ${ }^{64}$ EPA eventually succumbed to state pressure and allowed decentralized I/M programs to continue, and local testing by private facilities became the norm throughout most of the country. ${ }^{65}$ States gradually accepted the I/M mandate because of the need to

54. U.S. EPA, Inspection/Maintenance Flexibility Amendments, 60 Fed. Reg. 20934 (proposed Apr. 28, 1995).

55. U.S. EPA, Inspection/Maintenance Flexibility Amendments, 60 Fed. Reg. 48029 (Sept. 18, 1995).

56. 40 C.F.R. $\$ 51.355(\mathrm{a})(2017)$.

57. 40 C.F.R. $\$ 51.353$ (2017).

58. See State Officials Not Pleased EPA's Flexible Enhanced I/M Rule Still Does Not Address 50\% Discount, 6 Clean Air Rep. (Inside EPA) 19:19 (Sept. 21, 1995).

59. 40 C.F.R. $\$ 51.351(\mathrm{~g})(2016)$.

60. Pub. L. No. 104-59, 109 Stat. 568

61. Id. at 616 .

62. Id.

63. Id.

64. Minor Amendments to Inspection Maintenance Program Evaluation Requirements; Amendments to the Final Rule, 63 Fed. Reg. 1362 (Jan. 9, 1998) (codified at 40 C.F.R. $\$ 51.353(\mathrm{c})$ ).

65. Federalism and the Inspection and Maintenance Program, supra note 49, at 1514. develop SIP revisions for nonattainment areas that would satisfy EPA and avoid the onerous penalties for noncompliance with SIP requirements. ${ }^{66}$

\section{Testing Based on the Use of OBD Systems}

Since 1981, manufacturers of automobiles have used onboard computer systems to control engine operations. The early versions of the OBD system would detect a malfunction in the vehicle, and the malfunction indicator light (MIL, or the check engine warning light) would illuminate. ${ }^{67}$

The 1990 CAA Amendments required an OBD system to be standard on all LDVs with a gross vehicle weight up to 8,500 pounds. ${ }^{68}$ Beginning with MY 1996 vehicles, improved technology, known as OBD Generation II, or OBD II, was used. ${ }^{69}$ It became subject to federally mandated I/M diagnostic checks beginning in 2002. ${ }^{70}$ The statute directed EPA to promulgate regulations requiring manufacturers to install on all new LDVs and light-duty trucks (LDTs) diagnostic systems capable of the following:

(1) Accurately identifying emission-related system deterioration or malfunction, including, at a minimum, the catalytic converter and oxygen sensor, which could cause or result in failure of the vehicle to comply with emission standards for the vehicle's useful life,

(2) Alerting the vehicle's owner or operator to the likely need for emission-related components or systems maintenance or repair,

(3) Storing and retrieving fault codes specified by the administrator, and

(4) Providing access to stored information in a manner specified by the administrator. ${ }^{71}$

In addition, $\$ 202(\mathrm{~m})$ requires manufacturers to make available to interested persons all necessary emissionrelated maintenance and repair information, including information needed to make use of the OBD II system. ${ }^{72}$ Such information is to be provided according to regulations adopted by EPA. After regulations were promulgated, the states had two years to modify their I/M programs to provide for inspection of OBD systems and for maintenance or repair of malfunctions. ${ }^{73}$

66. The most important sanction is EPA's power to block transportation money from going to a noncompliant state. CAA $\$ 179(\mathrm{~b})(1)$, 42 U.S.C. $\$ 7509(\mathrm{~b})(1)$.

67. David Sosnowski \& Edward Gardetto, U.S. EPA, Performing Onboard Diagnostic Checks as Part of a Vehicle Inspection and Maintenance Program 3, 5 (2001) (EPA 420-R-01-015).

68. CAA $\$ 202(\mathrm{~m}), 42$ U.S.C. $\$ 7521(\mathrm{~m})$.

69. OBD II, OBD-II Background, http://www.obdii.com/background.html (last visited Aug. 3, 2017).

70. 40 C.F.R. $\$ 51.357(\mathrm{a})(12)(2002)$.

71. CAA $\$ 202(\mathrm{~m})(1), 42$ U.S.C. $\$ 7521(\mathrm{~m})(1)$.

72. CAA $\$ 202(\mathrm{~m})(5), 42$ U.S.C. $\$ 7521(\mathrm{~m})(5)$.

73. CAA $\$ 201(\mathrm{~m})(3), 42$ U.S.C. $\$ 7521(\mathrm{~m})(3)$. 
Under the 1990 CAA Amendments, states required to implement I/M programs were further required to incorporate an evaluation of the OBD computer as part of those programs. On November 5, 1992, EPA promulgated a final rule related to state air quality implementation plans for I/M programs. ${ }^{74}$ At the time the 1992 rule was published, certification regulations for OBD II had not been finalized, so EPA reserved space in the I/M rule to address OBD-I/M requirements at a later date. ${ }^{75} \mathrm{EPA}$ reported that 31 of the 33 state and local areas that require I/M tests incorporated the use of OBD technology into their I/M procedures. ${ }^{76}$

On February 19, 1993, EPA promulgated an updated final OBD II regulation. ${ }^{77}$ For LDVs and LDTs with gasoline engines, the rule requires that the OBD II system monitor the performance and detect malfunctions and deterioration of the catalyst and oxygen sensor and detect engine misfire. ${ }^{78}$ The OBD II system is required to detect the occurrence of a malfunction or deterioration of any other emission-related powertrain system or component that results in an exhaust emission increase greater than specified in the regulation. ${ }^{79}$ It must also detect the occurrence of any leakage or other malfunction of the vapor recovery or purge systems that result in evaporative emissions exceeding specified limits. ${ }^{80}$ The information identifying the likely problem must be stored in the vehicle's computer, and the MIL must be illuminated. ${ }^{81}$ There are separate requirements for vehicles with diesel engines. ${ }^{82}$

The rule also requires that the OBD II system monitor and detect electrical failure or disconnection of any emission-related component that, either directly or indirectly, sends information to, or receives information from, the vehicle's on-board computer. ${ }^{83}$ If an electrical disconnection occurs that prevents or limits the operation of the component, regardless of the emission effect, the MIL must be illuminated and a trouble code stored. ${ }^{84}$ The rule also contains anti-tampering provisions to protect the on-board computer from tampering, and to make inspection of the OBD II system an effective enforcement measure during I/M testing. ${ }^{85}$ Because the U.S. Court of Appeals for the District of Columbia (D.C.) Circuit vacated part of the regulations dealing with tampering involving the OBD II systems certified

74. U.S. EPA, Inspection/Maintenance Program Requirements, 57 Fed. Reg. 52950 (Nov. 5, 1992).

75. $I d$.

76. U.S. EPA, On-Board Diagnostics (OBD): Status of State and Local (OBD) Inspection/Maintenance (I/M) Programs, https://www.epa.gov/state-andlocal-transportation/board-diagnostics-obd-status-state-and-local-obd (last updated Aug. 2, 2016).

77. Control of Air Pollution From New Motor Vehicles and New Motor Vehicle Engines; Regulations Requiring On-Board Diagnostic Systems on 1994 and Later Model Year Light-Duty Vehicles and Light-Duty Trucks, 58 Fed. Reg. 9468 (Feb. 19, 1993)

78. Id. at 9471

79. Id

80. Id.

81. Id.

82. Id.

83. Id.

84. Id. at 9472

85. Id. to California's OBD II regulations, EPA modified its regulations on October 7, $1994 .{ }^{86}$

On August 18, 1995, EPA proposed modifications to the requirements applicable to $\mathrm{I} / \mathrm{M}$ inspections of the OBD II systems. ${ }^{87}$ On August 30, 1996, EPA promulgated a final rule revising the requirements associated with OBD II systems. ${ }^{88}$ This rulemaking promulgated appropriate revisions to federal OBD II regulations so that compliance with California's revised OBD II requirements satisfies federal requirements. ${ }^{89}$ On September 20, 2000, EPA proposed to allow states to use an analysis of the computerized OBD II systems in lieu of tailpipe tests and evaporative system purge and fill-neck pressure tests on MY 1996 or newer vehicles. ${ }^{90}$ The rule was finalized on April 5, 2001. ${ }^{91}$

EPA's regulations concerning OBD are found at 40 C.F.R. \$86.1806-05. They are largely based on California's regulations. ${ }^{92}$ For MY 2017 and later vehicles, OBD requirements are found at 40 C.F.R. $\$ 86.1806-17$. These regulations require the $\mathrm{OBD}$ II system to detect malfunctions or deterioration of emission-related components or elements of design before such malfunctions or deterioration individually cause emission increases above thresholds set by EPA. ${ }^{93}$ When a malfunction or deterioration is detected, the MIL will illuminate and a diagnostic trouble code (DTC) identifying the malfunction will be stored in the computer for later use by a repair technician..$^{94}$ The OBD II system is more accurate than tailpipe emissions tests because it tests the vehicle under a variety of operating conditions as the vehicle is used.

The OBD II test begins with a preliminary inspection of tires and components to assure the vehicle is safe to test. ${ }^{95}$ If safe, the MIL is checked to assure it is operable. ${ }^{96}$ Then, the information from the vehicle is entered into the emissions analyzer, which evaluates the status of the OBD II system's vehicle monitors. ${ }^{97}$ If the vehicle's monitors are operating properly, the test will continue. ${ }^{98}$ If no DTCs are

86. Control of Air Pollution From New Motor Vehicles and New Motor Vehicle Engines: Regulations Requiring Tampering Prevention for On-Board Diagnostic Systems, 59 Fed. Reg. 51114 (Oct. 7, 1994).

87. Inspection/Maintenance Program Requirement-On-Board Diagnostic Checks, 60 Fed. Reg. 43092 (Aug. 18, 1995).

88. Control of Air Pollution From New Motor Vehicles and New Motor Vehicle Engines: Regulations Requiring On-Board Diagnostic (OBD) SystemsAcceptance of Revised California OBD II Requirements, 61 Fed. Reg. 45898 (Aug. 30, 1996).

89. Id.

90. Amendments to Vehicle Inspection Maintenance Program Requirements Incorporating the Onboard Diagnostic Check, 65 Fed. Reg. 56844 (proposed Sept. 20, 2000).

91. Amendments to Vehicle Inspection Maintenance Program Requirements Incorporating the Onboard Diagnostic Check, 66 Fed. Reg. 18156 (Apr. 5, 2001) (codified at 40 C.F.R. pts. 51, 85).

92. Control of Air Pollution From Motor Vehicles: Tier 3 Motor Vehicle Emission and Fuel Standards, 79 Fed. Reg. 23688 (Apr. 28, 2014).

93. 40 C.F.R. $\$ 86.1806-17$ (a)(8) (2015).

94. Id. $\$ 86.1806-17(\mathrm{~b})(1)$.

95. Id.

96. Id.

97. Id.

98. Id. 
found, the vehicle will pass the OBD II test. ${ }^{99}$ The use of the OBD II system makes it difficult to quantify the pollutants reduced from the I/M programs because the system's approach is based on early discovery of malfunctions to prevent emissions of pollutants.

\section{The Role of I/M in Enforcement of the CAA}

\section{A. History of I/M Enforcement}

The I/M program can be utilized to assist in implementing at least three programs concerning mobile source emission control. First, the I/M program can be used to assure the emission controls that were incorporated into the vehicle continue to function for the life of the vehicle, as specified in the CAA. ${ }^{100} \mathrm{I} / \mathrm{M}$ can be used to identify categories of vehicles that fail to conform to the applicable emission regulations, which can lead to EPA requiring the manufacturer to remedy the nonconformity. ${ }^{101}$ For example, heavyduty diesel-powered vehicles of MY 2007 and later have been subject to an enforceable program for testing in-use vehicles. ${ }^{102}$ However, there is little evidence that the I/M program has played a significant role in implementing these recall requirements. ${ }^{103}$

Second, the I/M program can function to catch manufacturers that use defeat devices to avoid complying with the CAA's provision for motor vehicle emission standards. ${ }^{104}$ Section 203(a)(1) of the CAA prohibits the sale of vehicles that do not conform to the provisions of an approved certificate of conformity (COC) issued by EPA to manufacturers. ${ }^{105}$ Section 203(a)(3)(b) prohibits the use of components intended to defeat or bypass pollution controls. ${ }^{106}$ Violators are subject to a maximum civil penalty of $\$ 37,500$ per day, adjusted for inflation. ${ }^{107}$

The "knowing violation" provision found in CAA $\$ 113(\mathrm{c})(1)$ does not apply to mobile source violations. However, CAA \$113(c)(2) provides for criminal fines and imprisonment for up to two years for false statements and certifications, which includes any person who knowingly "falsifies, tampers with, renders inaccurate, or fails to install any monitoring device or method required to be maintained or followed under this chapter." 108 More-

99. Salt Lake County Health Department, Health Regulation \#22, Vehicle Emissions Control Program, \$4.3.6 and app. A.

100. CAA $\$ 207,42$ U.S.C. $\$ \$ 207$ (a), 7541. The useful life of a vehicle is defined at CAA $\$ 202(\mathrm{~d}), 42$ U.S.C. $\$ 7521(\mathrm{~d})$.

101. CAA $\$ 207(\mathrm{c}), 42$ U.S.C. $\$ 7541(\mathrm{c})$.

102. Control of Emissions of Air Pollution From New Motor Vehicles: In-Use Testing for Heavy-Duty Diesel Engines and Vehicles, 70 Fed. Reg. 34594, 34595 (June 14, 2005).

103. See generally U.S. EPA, 2012-2013 Progress Report Vehicle Engine Compliance Activities 24 (2015) (EPA-420-R-15-007).

104. CAA $\$ 202(a), 42$ U.S.C. $\$ 7521(\mathrm{a})$.

105. 42 U.S.C. $\$ 7522(\mathrm{a})(1)$.

106. Id. \$7522(a)(3)(b) \& (a)(1). Penalties are found at CAA \$205(a), 42 U.S.C. $\$ 7424(\mathrm{a})$.

107. The statutory penalties after adjustment for inflation are found at 40 C.F.R. $\$ 19.4$, tbl. 1 (2017).

108. CAA $\$ 113(\mathrm{c})(2)(\mathrm{C}), 42$ U.S.C. $\$ 7413(\mathrm{c})(2)(\mathrm{C})$. over, CAA $\$ 203(\mathrm{a})(3)(\mathrm{B})$ makes it a violation to sell any part or component of a motor vehicle intended to "bypass, defeat, or render inoperative any device" installed to comply with CAA regulations. ${ }^{109}$ The criminal enforcement provisions of CAA $\$ 113(\mathrm{c})$ appear to cover $\$ 203(\mathrm{a})(3)(\mathrm{B})$ violations. The criminal provisions found in Title 18 also may be used in cases involving CAA violations, which is discussed below.

Since the beginning of the federal program to control emissions from motor vehicles, numerous manufacturers have schemed to avoid complying with the mobile source emission control requirements. Unfortunately, as discussed below, despite I/M programs, vehicle manufacturers often have been able to avoid detection of their violations, sometimes for years. Moreover, when violations are discovered, penalties, until recently, were not severe enough to discourage illegal behavior. Thus, I/M programs have played a minor role in preventing violations by the motor vehicle industry.

In 1973, EPA accused Volkswagen of selling MY 1973 vehicles that used a temperature-sensing device to cut out pollution controls at low temperatures. Volkswagen settled for a fine of $\$ 120,000$ without admitting any wrongdoing. ${ }^{110}$ In 1995, EPA and the U.S. Department of Justice (DOJ) accused General Motors of using a computer chip that changed combustion parameters on 470,000 Cadillac sedans that resulted in increased emissions when the vehicles' air conditioning and heating were being used. ${ }^{111}$ The federal test procedure (FTP) at that time did not include emissions testing when the air conditioning was operating. ${ }^{112}$ EPA alleged that the vehicles were tampered with because emissions were higher during non-FTP operational conditions. ${ }^{113}$ On November 20, 1995, General Motors agreed to recall nearly 500,000 late-model Cadillacs, pay an \$11 million fine, and establish an "emission remedial project fund" of at least $\$ 7.05$ million to be used to replace older buses and fleet vehicles with less polluting vehicles. ${ }^{114}$ Compliance costs totaled about $\$ 45$ million. ${ }^{115}$

In 1998, EPA settled with seven heavy-duty truck engine manufacturers that allegedly equipped their diesel engines with "defeat devices" by installing software that could detect when the engine was being tested under the FTP and then control the vehicle's combustion process to produce legal emissions. ${ }^{116}$ When the engines were used on

109. 42 U.S.C. $\$ 7522(\mathrm{a})(3)(\mathrm{B})$.

110. Jeff Plungis, Carmaker Cheating on Emissions Almost as Old as Pollution Tests, 46 Env't Rep. (BNA) 2811 (Sept. 25, 2015).

111. John Cushman, Half-Million Cadillacs Recalled in Federal Pollution Settlement, N.Y. Times, Dec. 1, 1995.

112. Id.

113. Id.

114. See GM to Recall 470,000 Cadillacs, Pay Fine Over Charge That Device Raised Emissions, Daily Env't Rep. (BNA), at AA-1 (Dec. 1, 1995).

115. Statement of Carol Browner, Administrator, U.S. EPA, DOJ/EPA Press Conference, Settlement, GM Enforcement Action (Nov. 20, 1995), available at 1995 WL 705249.

116. The seven manufacturers include: Caterpillar, Inc.; Cummins Engine Co.; Detroit Diesel Corp.; Mack Trucks, Inc.; Navistar International Transportation Corp.; Renault Vehicles Industrials, S.A.; and Volvo Truck 
the road, the engine operation would change to be more fuel-efficient, but would produce up to three times the legal limit of $\mathrm{NO}_{x} \cdot{ }^{117}$ The companies paid a civil penalty of $\$ 83.4$ million to settle the case that led to about $\$ 1$ billion in total costs to the companies. ${ }^{118}$ The manufacturers settled separately with the California Air Resources Board in 1998, agreeing to pay fines and fund programs to mitigate the $\mathrm{NO}_{\mathrm{x}}$ emissions that the nonconforming engines would generate in California. ${ }^{119}$

Also in 1998, Honda was alleged to have used emissions defeat devices and paid a civil penalty of $\$ 12.6$ million and incurred remedial costs of $\$ 250$ million. ${ }^{120}$ Ford Motor Co. in the same year faced similar allegations and paid a civil penalty of $\$ 2.2$ million and incurred remedial costs estimated at $\$ 7.5$ million. ${ }^{121}$ In 2005 , Volkswagen was accused of having defective emissions controls and paid a civil penalty of $\$ 1.1$ million and incurred costs of $\$ 27.9$ million to fix the problem. ${ }^{122}$ Also in 2005, a similar claim was made against DaimlerChrysler Corp., which paid a civil penalty of $\$ 1$ million and incurred about $\$ 94$ million in remedial costs. ${ }^{123}$ In 2006, Mercedes-Benz paid a civil penalty of $\$ 1.2$ million and incurred costs of $\$ 60.2$ million for vehicles with defective emissions controls. ${ }^{124}$

Corp. Press Release, DOJ, EPA Announce One Billion Dollar Settlement With Diesel Engine Industry for Clean Air Violations (Oct. 22, 1998), available at https://yosemite.epa.gov/opa/admpress.nsf/b1ab9f485b09897 2852562e7004dc686/93e9e651adeed6b7852566a60069ad2e?OpenDocu ment.

117. Steven A. Herman, Clean Air Act Settlement With Diesel Engine Makers Is Historic in Size, Scope, and Environmental Impact, 13 NaT'L EnvtL. ENFORCEMENT J. 10:18 (1998).

118. Patrick Ambrosio, EPA Expected to Seek Significant Penalty Over Volkswagen's Use of Defeat Devices, 46 Env't Rep. (BNA) 2902 (Oct. 2, 2015).

119. United States v. Caterpillar, 227 F. Supp. 2d 73, 77, 33 ELR 20034 (D.D.C. 2002); Carolyn Whetzel, State Regulators Criticize Slow Pace of Manufacturers' Effort to Retrofit Diesels, 34 Env't Rep. (BNA) 2778 (Dec. 19, 2003). Part of the settlement included a stipulation that the manufacturers would develop software to correct the problem and install it when engines are rebuilt or the vehicle owners request "reflashing" to reprogram a vehicle's computer software. Many trucks, however, were not rebuilt and the Engine Manufacturers Association (EMA) litigated to avoid compliance. See Marivel De la Torre et al., California Environmental Protection Agency, Air Resources Board, Report of Enforcement Activities: January 1-December 31, 2004, at 12 (2005) (noting that the "mandatory reflash program will be imposed"), http://www.arb.ca.gov/enf/ reports/04enfrpt.pdf. On Oct. 16, 2006, the Superior Court of California, County of Sacramento, ruled in favor of EMA, holding that California did not have statutory authority to require manufacturers to develop, provide, or install software, but the court held that the settlement agreement could be enforced. Court Rejection of California Engine Fix Rule May Deter Other States, 17 Clean Air Rep. (Inside EPA) 21:15 (Oct. 19, 2006).

120. Honda Settles Emissions Suit, CNNMoney, June 8, 1998, http://money.cnn. com/1998/06/08/companies/honda/index.htm.

121. Ambrosio, supra note 118, at 2904.

122. Press Release, U.S. EPA, Volkswagen of America, Inc., Agrees to Pay More Than $\$ 1$ Million for Clean Air Act Violation (June 15, 2005), available at https://yosemite.epa.gov/opa/admpress.nsf/b1ab9f485b098972852562e70 04dc686/6946eeaadcfa982b8525702100777c0e.

123. Press Release, U.S. EPA, U.S. Announces $\$ 94$ Million Clean Air Act Settlement With Chrysler Over Emission Control Defects on 1.5 Million Jeep and Dodge Vehicles (Dec. 21, 2005), available at https://yosemite.epa. gov/opa/admpress.nsf/68b5f2d54f3eefd28525701500517fbf/1751045d23 87854f852570de006ea56a!OpenDocument.

124. Press Release, U.S. EPA, Mercedes-Benz Pays \$1.2 Million for Clean Air Act Violation, Also Spends \$59 Million for Voluntary Recall (Dec. 21, 2006), available at https://yosemite.epa.gov/opa/admpress.nsf/198a007cc 57e64d3852570210055f3f6/03fffa1d2e87aafc8525724b005e930b!Open Document.
In 2014, Hyundai and Kia were accused of overstating the fuel economy of their vehicles. ${ }^{125}$ This led to a $\$ 100$ million civil penalty and at least $\$ 350$ million in total costs. ${ }^{126}$ On October 8, 2016, DOJ announced a settlement with Detroit Diesel Corp. concerning the company's sale of 7,786 heavy-duty diesel engines in 2010 that were not certified by EPA and did not meet the applicable CAA emission standards. ${ }^{127}$ The company settled the case by agreeing to spend $\$ 14.5$ million on projects to reduce emissions and to pay a $\$ 14$ million civil penalty. ${ }^{128}$

\section{B. The Volkswagen Case}

Despite widespread efforts by motor vehicle manufacturers to use defeat devices to avoid complying with the CAA's emissions requirements, the I/M program has not been an effective tool for detecting cheating. This has continued, as demonstrated by Volkswagen's extensive cheating on its CAA obligations. On September 18, 2015, EPA announced that 482,000 Volkswagen diesel engine vehicles sold for many years in the United States were programmed to pass emissions tests, but when operated under normal driving conditions, they emitted air pollutants well above the legal limit. ${ }^{129}$

This cheating was not discovered by EPA or by staterun I/M programs. ${ }^{130}$ The International Council on Clean Transportation (ICCT), a European environmental group, wanted to have U.S. technology adopted for European motor vehicles because Volkswagen appeared to be meeting U.S. emission standards that were more stringent than Europe's. ${ }^{131}$ The ICCT funded West Virginia's Center for Alternative Fuels, Engines, and Emissions (CAFEE) to study emissions from real-world driving of Volkswagen models. ${ }^{132}$ The CAFEE researchers concluded that the vehicles' emissions were exceeding the CAA standards by five to 35 times. ${ }^{133}$ This resulted in investigations by EPA and California, and on September 3, 2015, Volkswagen admitted that it deliberately outfitted its cars with defeat devices. ${ }^{134}$

Volkswagen later announced about 11 million diesel vehicles were sold worldwide with diesel engines that

125. Press Release, U.S. EPA, United States Reaches Settlement With Hyundai and Kia in Historic Greenhouse Gas Enforcement Case (Nov. 3, 2014), available at https://archive.epa.gov/epapages/newsroom_archive/newsreleas es/15519081fbf $4002285257 \mathrm{~d} 8500477615 . \mathrm{html}$

126. Ambrosio, supra note 118, at 2903.

127. Press Release, DOJ, Detroit Diesel Corporation to Pay Penalty and Reduce Exposure to Harmful Diesel Exhaust to Resolve Clean Air Act Violations (Oct. 6, 2016)

128. Id.

129. Volkswagen Official to Testify Before Congress, 46 Env't Rep. (BNA) 3011 (Oct. 9, 2015)

130. Charlotte Alter, The Man Who Brought Down Volkswagen, Time, Nov. 30/ Dec. 7, 2015, at 100.

131. Dune Lawrence et al., How Could Volkswagen's Top Engineers Not Have Known, Bloomberg Businessweek, Oct. 26/Nov. 1, 2015, at 52.

132. Alter, supra note 130.

133. Lawrence et al., supra note 131, at 52.

134. Patrick Ambrosio, Volkswagen CEO Steps Down Amid Scandal Over Admissions of Pollution-Test Cheating, 46 Env't Rep. (BNA) 2805 (Sept. 25, 2015). 
violate the law. ${ }^{135}$ Volkswagen inserted lines in the computer code that controls engine performance to activate the emissions controls when driving patterns are consistent with the testing protocol. But when the vehicle's operation is consistent with normal road use, the engine is programmed to maximize fuel economy, which increases emissions dramatically. ${ }^{136}$

On January 4, 2016, DOJ filed a civil complaint against Volkswagen, Audi, and Porsche for violations involving about 500,000 two-liter diesel engine vehicles and about 85,000 three-liter diesel engines. ${ }^{137}$ The complaint alleged violation of the CAA's $\$ 203(\mathrm{a})(1)$, (a)(2), (a)(3)(A), and (a) (3)(B). ${ }^{138}$ In addition, many states, business interests, and individuals brought enforcement actions. ${ }^{139}$ In June 2016, EPA's Administrator announced a proposed partial consent decree of its civil liability action for violations by 20092015 two-liter diesel vehicles that include a vehicle buyback program, a $\mathrm{NO}_{\mathrm{x}}$ reduction program, and a program to advance the use of zero emissions vehicles (ZEVs). ${ }^{140} \mathrm{It}$ did not resolve the many private law suits, or the potential actions for CAA-based civil penalties or criminal prosecutions. ${ }^{141}$ Volkswagen also installed defeat devices on its 2009-2016 vehicles with three-liter diesel engines. On July 13, 2016, the California Air Resources Board rejected Volkswagen's proposed recall for about 85,000 three-liter diesel vehicles sold in the United States. ${ }^{142}$

135. Arne Delfs et al., Volkswagen Will Recall 8.5M Diesels After German Agency Takes Hard Line, 46 Env't Rep. (BNA) 3076 (Oct. 16, 2015); Andrea Barbara Schuessler, Volkswagen Admits Europe Manipulations, Germany's Transport Minister Reveals, 46 Env't Rep. (BNA) 2809 (Sept. 25, 2015).

136. Lawrence et al., supra note 131, at 52.

137. Press Release, DOJ, United States Files Complaint Against Volkswagen, Audi, and Porsche for Alleged Clean Air Act Violations (Jan. 4, 2016), available at https://www.justice.gov/opa/pr/united-states-filescomplaint-against-volkswagen-audi-and-porsche-alleged-clean-air-act; Patrick Ambrosio, Federal Government Files Lawsuit Against Volkswagen Over Diesel Emissions Scandal, 47 Env't Rep. (BNA) 97 (Jan. 8, 2016); Leslie Pappas, New Jersey Latest to Sue Volkswagen Alleging Consumer Fraud, Air Violations, 47 Env't Rep. (BNA) 444 (Feb. 12, 2016).

138. Curt Barry, EPA Files Suit Over VW "Defeat Devices" Seeking "Significant" Penalties, 27 Clean Air Rep. (Inside EPA) 1:19 (Jan. 14, 2016).

139. By the end of October 2015, at least 80 consumer lawsuits had been filed in the United States on behalf of consumers that purchased or leased 482,000 Volkswagen and Audi diesel vehicles. Jabeen Bhatti, Environmental Groups Worry VW Scandal May Cripple Green "Made in Germany" Reputation, 46 Env't Rep. (BNA) 3155 (Oct. 23, 2015). The U.S. Judicial Panel on Multidistrict Litigation transferred these consumer lawsuits to the U.S. District Court for the Northern District of California. On Feb. 22, 2016, three class action lawsuits were filed against Volkswagen on behalf of (1) consumers who purchased or leased affected Volkswagen vehicles; (2) automobile dealers who had affected diesel vehicles in their inventory on Sept. 18, 2015; and (3) automobile dealers that competed with Volkswagen that were disadvantaged by Volkswagen's false marketing. Patrick Ambrosio, Plaintiffs File Three Class Action Complaints Over Volkswagen Diesel Emissions Cheating, 47 Env't Rep. (BNA) 596 (Feb. 26, 2016); Margaret Cronin Fisk, V.W. Sued by U.S. Franchise Dealers for Losses Arising From Diesel Scandal, 47 Env't Rep. (BNA) 1031 (Apr. 8, 2016).

140. Patrick Ambrosio, "Ground-Breaking"VW Settlement Would Require as Much as \$14.7 Billion, 47 Env't Rep. (BNA) 1973 (July 1, 2016).

141. Anthony Lacey, McCarthy Says "More to Come" After Historic \$24.7 Billion VW Emissions Deal, 27 Clean Air Rep. (Inside EPA) 13:11 (June 30, 2016); Patrick Ambrosio, Civil, Criminal Charges Still Possible After \$14.7 Billion Volkswagen Diesel Settlement, 47 Env't Rep. (BNA) 1975 (July 1, 2016).

142. Carolyn Whetzel, California Rejects Volkswagen's Recall Plan for 3-Liter Diesels in Emissions Scandal, 47 Env't Rep. (BNA) 2141 (July 15, 2016).
On October 25, 2016, U.S. District Court Judge Charles Breyer approved the Volkswagen settlement of up to $\$ 10$ billion to compensate consumers, $\$ 2.7$ billion for environmental mitigation measures, and $\$ 2$ billion to promote ZEVs. ${ }^{143}$ Owners of approximately 475,000 Volkswagens and Audis with two-liter engines can choose to have Volkswagen buy back their vehicles for the trade-in price on September 15, 2015, or have the vehicle repaired. ${ }^{144}$ Volkswagen will also pay up to $\$ 332.5$ million in attorney fees and costs as well as $\$ 1.2$ billion to its 652 U.S. dealers. ${ }^{145}$

In December 2016, a new agreement was proposed that would require the three-liter diesels to be brought into compliance or be bought back by Volkswagen, and the company would pay another $\$ 225$ million into the pollution-reduction trust fund. ${ }^{146}$ On December 20, 2016, Volkswagen reached a $\$ 1$ billion settlement involving about 83,000 MY 2009-2016 Audi, Volkswagen, and Porsche vehicles with three-liter diesel engines. ${ }^{147}$ It appears that the three-liter diesel vehicles can be fixed, which will avoid the costs of a buyback program. ${ }^{148}$

On September 9, 2016, a former Volkswagen engineer, James Liang, pleaded guilty to conspiring to defraud the United States and violate the CAA, which was the first criminal case to develop from Volkswagen's cheating. ${ }^{149} \mathrm{He}$ is cooperating with prosecutors. ${ }^{150}$ On February 23, 2017, a Volkswagen engineer, Oliver Schmidt, was arrested while on vacation in Florida and charged with fraud and conspiracy. ${ }^{151}$ He pleaded guilty on August 11, 2017, in the federal District Court for the Eastern District of Michigan, and sentencing is scheduled for December 6, 2017. ${ }^{152}$ Other Volkswagen employees have been indicted, but they are in Germany and are protected from extradition. ${ }^{153}$ On April 21, 2017, Volkswagen agreed to pay a

143. There is a separate agreement with California that involves Volkswagen spending $\$ 800$ million over 10 years to help build the state's zero-emission infrastructure and support the electric vehicle market. As of July 2017, the details of the agreement were still being negotiated. See Carolyn Whetzel, VW Revamps Zero-Emissions Vehicle Plan to Woo California, Daily Env't Rep. (BNA) (July 3, 2017).

144. Sudhin Thanawala \& Tom Krisher, Judge Approves $\$ 15$ Billion VW EmissionsCheating Settlement, Salt Lake Trib., Oct. 26, 2016, at A3.

145. Kartikay Mehrotra, VW, Dealers Propose \$1.2 Billion Agreement for Losses From Emissions-Cheating Scandal, 47 Env't Rep. (BNA) 2865 (Oct. 7, 2016).

146. David LaRoss, EPA Reaches New Pact With Volkswagen, Class Settlement Likely, 27 Clean Air Rep. (Inside EPA) 26:8 (Dec. 29. 2016).

147. Kartikay Mehrotra, VW Reaches Deal for Emissions-Cheating Audi, Porsche Models, Law Energy \& Climate Rep. (BNA) (Dec. 21, 2016).

148. LaRoss, supra note 146.

149. Tom Schoenberg et al., Veteran Volkswagen Engineer Is First Charged in U.S. Diesel Emissions Probe, 47 Env't Rep. (BNA) 2687 (Sept. 16, 2016).

150. Jamie Butters et al., Volkswagen Pleads Guilty in U.S. Emissions-Cheating Scandal, Law Energy \& Climate Rep. (BNA) (Mar. 10, 2017).

151. Margaret Cronin Fisk \& Keith Naughton, VW Executive Pleads Not Guilty as 5 Avoid U.S. Diesel Case, Law Energy \& Climate Rep. (BNA) (Feb. 23, 2017).

152. Margaret Cronin Fisk \& Brian Louis, VW Executive Schmidt Pleads Guilty in Auto Emissions Scandal, Env't Rep. (BNA) (Aug. 11, 2017).

153. Id. Giovanni Pamio, an Italian living in Germany, was the eighth person charged by DOJ. He is not a German citizen, which means he could be subject to extradition, but he was arrested in Germany, which takes precedence over the U.S. charges. Karin Matussek \& Christoph Rauwald, Ex-Audi Manager Charged in U.S. Over VW Emissions Scandal, Daily Env't Rep. (BNA) (July 10, 2017). 
criminal fine of $\$ 2.8$ billion and civil penalties of $\$ 1.5$ billion for misleading U.S. regulators and customers. ${ }^{154} \mathrm{On}$ May 19, 2017, EPA approved Volkswagen's fix for 84,391 MY 2012-2014 Passat sedans with two-liter diesel engines and automatic transmissions. ${ }^{155}$

However, as of July 2017, no criminal indictments of any senior Volkswagen executives have been announced, although the DOJ investigation continues. Volkswagen's chief executive officer, Martin Winterkorn, is also under investigation in Germany. ${ }^{156}$ Criminal penalties imposed against corporate executives have an important role to play when the management is willing to risk the organizations' assets in order to make a profit. Moreover, criminal penalties are unmatched for their deterrent effect, and a single successful criminal prosecution may result in improved compliance by an entire industry. ${ }^{157}$ Nevertheless, no senior executive in the automotive industry has ever been criminally prosecuted for tampering violations of the CAA.

\section{Enforcement Against Corporations and Individuals}

After decades of actions by the automotive companies to cheat on emissions requirements, EPA and DOJ appeared to be moving to a more-aggressive enforcement position. On September 9, 2015, DOJ released its memorandum "Individual Accountability for Corporate Wrongdoing" over the signature of Deputy Attorney General Sally Quillian Yates. ${ }^{158}$ The Yates Memo reflected a policy shift to strengthen the efforts to pursue individual corporate wrongdoers based on six key steps. They are as follows:

(1) in order to qualify for any cooperation credit, corporations must provide to the Department all relevant facts relating to the individuals responsible for the misconduct; (2) criminal and civil corporate investigations should focus on individuals from the inception of the investigation; (3) criminal and civil attorneys handling corporate investigations should be in routine communication with one another; (4) absent extraordinary circumstances or approved departmental policy, the Department will not release culpable individuals from civil or criminal liability when resolving a matter with the corporation; (5) Department attorneys should not resolve matters with a corporation without a clear plan to resolve related individual cases, and should memorialize any declinations as to individuals in such cases; and (6) civil attorneys should consistently focus on individuals as well as the company and evalu-

154. Margaret Cronin Fisk \& Tom Schoenberg, VW's \$4.3 Billion U.S. Deal Completed With Court's Approval, Law Energy \& Climate Rep. (BNA) (Apr. 21, 2017).

155. Ryan Beene, U.S. Regulators Approve Emissions Fix for Volkswagen Diesels, Law Energy \& Climate Rep. (BNA) (May 19, 2017).

156. Fisk \& Naughton, supra note 151

157. See generally ARnold W. Reitze JR., Air Pollution Control and Climate Change Mitigation Law 308-10, 318-19 (2d. ed 2010).

158. Memorandum from Sally Quillian Yates, Deputy Attorney General, DOJ (Sept. 9, 2015) (Individual Accountability for Corporate Wrongdoing), available at https://www.justice.gov/dag/file/769036/download. ate whether to bring suit against an individual based on considerations beyond that individual's ability to pay. ${ }^{159}$

The Yates Memo may have signaled a more-aggressive posture by DOJ toward individuals violating the CAA. However, it is not clear if this aggressiveness applies to senior executives. After the release of the Yates Memo, EPA brought an enforcement action against the Harley-Davidson Motor Co. for selling more than 324,000 parts ("super tuners") designed to defeat the emission control on highway motorcycles. ${ }^{160}$ On August 18, 2016, the case was settled with a consent decree that requires the defendants to pay a civil penalty of $\$ 12$ million, spend $\$ 3$ million to reduce air pollution, and comply, in the future, with CAA requirements to include obtaining a valid COC before introducing into commerce a new motorcycle. ${ }^{161}$ In July 2017, DOJ dropped the $\$ 3$ million penalty based on a new policy of U.S. Attorney General Jeff Sessions, but this action will require a revised consent decree to be approved by a federal judge. ${ }^{162}$ This exercise of prosecutorial discretion stands in contrast to the penalties, discussed below, that have been imposed on mechanics working as I/M inspectors.

In May 2017, DOJ announced it planned to sue Fiat Chrysler Automobiles NV for installing illegal defeat devices, which carries a potential penalty of $\$ 4.6$ billion. ${ }^{163}$ On May 23, 2017, the United States brought a civil action in the U.S. District Court for the Eastern District of Michigan against FCA US LLC, Fiat Chrysler Automobiles NV, VM Motori S.p.A., and VM North America, Inc. ${ }^{164}$ The action seeks injunctive relief and civil penalties for violating CAA $\$ \$ 204$ and 205 and the related regulations. ${ }^{165}$ The defendants allegedly sold approximately 103,828 MY 20142016 diesel-fueled new motor vehicles under the Ram 1500 and Jeep Grand Cherokee model names. The defendants allegedly used at least eight software-based features called auxiliary emission control devices (AECDs) that were not included in the disclosures made as part of the COC applications. The defendants allegedly installed AECDs that caused the emission control system to underperform or shut off unless the vehicle was operating within the parameters of the federal emission tests. The use of these AECDs resulted in the vehicles emitting substantially higher levels of $\mathrm{NO}_{x}$ during normal driving conditions than during federal emission tests.

A new motor vehicle containing an AECD that was not disclosed results in the vehicle not being covered by the COC, which means it is prohibited from being sold in the United States. ${ }^{166}$ Moreover, no new vehicle may be

159. Id.

160. United States v. Harley-Davidson, Inc., No. 16-1687 (D.D.C. Aug. 18, 2016).

161. Id.

162. David Shepardson, U.S. Justice Department Drops \$3 Million HarleyDavidson Emissions Penalty, Reuters, July 20, 2017.

163. Ryan Beene et al., U.S. Said to Ready Lawsuit Over Fiat Chrysler Diesel Emissions, Env't Rep. (BNA) (May 19, 2017).

164. United States v. FCA US LLC et al., No. 2:17-cv-11633-JCO-EAS (E.D. Mich. May 23, 2017).

165. 42 U.S.C. $\$ \$ 7523,7524$; 40 C.F.R. pt. 86 (2017).

166. CAA $\$ 203(\mathrm{a})(1), 42$ U.S.C. $\$ 7522(\mathrm{a})(1)$. 
equipped with a defeat device, as defined at 40 C.F.R. $\$ 86.1803-01$. In addition, the CAA makes it illegal to remove emission control devices or to use any device intended to bypass, defeat, or render inoperative any device used to control emissions. ${ }^{167}$

Pursuant to CAA $\$ 203(\mathrm{a})(1)$ and (a)(3)(A), violations are subject to penalties of up to $\$ 37,500$ per motor vehicle for violations prior to November 3, 2015, and \$45,268 for each violation occurring on or after that date. The violation of $\$ 203(\mathrm{a})(3)(B)$, involving the sale or installation of defeat devices, provides for penalties that are $10 \%$ of the penalties of $\$ 203(a)(1)$ and (a)(3)(A). ${ }^{168}$

It is apparent that the $\mathrm{I} / \mathrm{M}$ program has not played more than a minor role in assuring compliance by the automotive industry with the CAA's emission control requirements. The automotive industry's cheating has been too sophisticated for the states to control through their I/M programs. Thus, the I/M program is focused on its third role, which is to prevent tampering and assure that vehicles in the hands of consumers continue to control emissions in a manner consistent with the manufacturer's COC.

For many years, the I/M program was based on tailpipe tests. These tests were relatively easy to thwart and enforcement actions were rare. With the development of more-sophisticated motor vehicle technology and the use of OBD-based testing, it became more difficult to cheat on the tests and it became easier to successfully bring enforcement actions against violators. However, although the CAA is a complex and comprehensive statute, Congress did not provide strong criminal sanctions for violating $\mathrm{I} / \mathrm{M}$ provisions.

Title II of the CAA provides only civil penalties for tampering with motor vehicle emissions controls. I/M is primarily the responsibility of the states, with EPA regulations requiring specified processes to be instituted by the states and approved by EPA. Most states provide civil penalties and/or misdemeanor penalties for I/M violations. ${ }^{169} \mathrm{DOJ}$ has increased its enforcement efforts since about 2009 by bringing actions based on the more general and ambiguous provisions of the federal criminal code found in Title 18 of the U.S. Code, which provides more-stringent penalties. Some of the statutes that potentially may be applied include crimes against the United States (18 U.S.C. \$2); a false claim (18 U.S.C. \$287); conspiracy to commit offense or to defraud the United States (18 U.S.C. \$371); false statements made to the U.S. government (18 U.S.C. $\$ 1001$ ); mail fraud (18 U.S.C. \$1341); fraud by wire, radio, or television (18 U.S.C. \$1343); and obstruction of justice (18 U.S.C. $\$ \$ 1503,1505,1510,1512-1514$, and 1517-1519). Under 18 U.S.C. $\$ 1503$, the government does not have to prove actual obstruction of justice, only the intent to obstruct justice. ${ }^{170}$

167. CAA $\$ 203(\mathrm{a})(3)(\mathrm{A}) \&(\mathrm{~B}), 42$ U.S.C. $\$ 7522(\mathrm{a})(3)(\mathrm{A}) \&(\mathrm{~B})$.

168. 42 U.S.C. $\$ 7522(\mathrm{a})$.

169. See, e.g., La. Rev. Stat. \$32:1312, Civil Penalties; Salt Lake County Health Department, Health Regulation \#22, app. B.

170. See United States v. Aguilar, 515 U.S. 593, 599 (1995).
The Yates Memo makes it clear that a corporation seeking credit for cooperation when penalties are being negotiated must identify all individuals involved in or responsible for the misconduct, regardless of their status or seniority. ${ }^{171}$ As discussed below, nearly all the I/M criminal enforcement actions brought by DOJ have involved prosecutions of low-level criminals who are almost always emissions inspectors.

On June 29, 2011, three inspectors at an emissions inspection station in Georgia were sentenced for issuing more than 1,400 fraudulent emissions certificates in violation of Georgia's law, for which they received payment well in excess of the going rate for an emissions test. ${ }^{172}$ One of the defendants was sentenced to two years of incarceration, followed by one year of supervised release, because of his prior criminal history. A second defendant was sentenced to 180 days of home confinement, as part of a two-year term of probation, and 50 hours of community service. A third defendant was sentenced to 120 hours of home confinement as part of a two-year term of probation. ${ }^{173}$

On April 9, 2012, a licensed North Carolina emissions inspector, of Durham, North Carolina, pleaded guilty to conspiring to violate the CAA and to making false statements. ${ }^{174}$ He used a surrogate vehicle ("clean scanning") rather than the customers' vehicles, which would have failed the emissions inspection, in order to falsely pass 353 vehicles. ${ }^{175}$

In 2012, five defendants in Charlotte, North Carolina, were sentenced for using a device to bypass the OBD system and provide false information that allowed the vehicles to pass an I/M test. ${ }^{176}$ The defendants were subject to probation and/or home detention, and/or community service and fines, but two defendants received prison sentences of 60 days and five months. ${ }^{177}$ One of the defendants used an illegally purchased OBD II simulator to falsify emissions in violation of North Carolina's vehicle emissions program for which he was sentenced to 24 months' probation, which included six months of home detention, and was ordered to perform 150 hours of community service. ${ }^{178}$

On October 19, 2012, two defendants were sentenced for conducting false vehicle inspections at two repair shops in Charlotte, North Carolina. ${ }^{179}$ One of the defendants, a licensed inspector, conducted 236 false vehicle inspections using a surrogate vehicle to produce false passing results, for which he was fined $\$ 7,500$, given three months in prison followed by three months of home confinement, and ordered to serve 50 hours of community service. ${ }^{180}$ The

\footnotetext{
171. Steven A. Lauer, Corporate Officers Take Note: Justice Department Is Telling U.S. Attorneys to Aim High, 47 Env't Rep. (BNA) 869 (Mar. 18, 2016).

172. DOJ, Environmental Crimes Section Monthly Bulletin 22 (Aug. 2011).

173. Id.

174. U.S. EPA, Environmental Crimes Bulletin 6 (Apr. 2012).

175. Id.

176. U.S. EPA, Environmental Crimes Bulletin 9 (Oct. 2012); DOJ, Environmental Crimes Section Monthly Bulletin 11 (Aug. 2011).

177. Id.

178. Id.

179. U.S. EPA, Environmental Crimes Bulletin 8 (Oct. 2012).

180. Id.
} 
other defendant was a licensed inspector and the owneroperator of a repair facility who used surrogate vehicles to falsely pass cars that would otherwise have failed the emissions inspection, for which he was paid. ${ }^{181}$ He was sentenced to four months in prison to be followed by four months of home confinement, and he was ordered to serve 50 hours of community service. ${ }^{182}$

Because these defendants participated in providing false certification of the emissions inspection requirements, they are guilty of violating CAA $\$ 113(\mathrm{c})(2)(\mathrm{A})$. Some of these defendants used equipment to provide false data that allowed the vehicles to pass inspection. There is no indication that any person who supplied the equipment to improperly pass vehicles that would otherwise fail was prosecuted. Such a person would appear not to be covered by $\$ 113(\mathrm{c})(2)(\mathrm{A})$, which is why the government would seek to use Title 18 .

The government rarely brings criminal actions against executives of large corporations for violations of environmental laws. The CAA provides criminal, civil, and administrative penalties for violation of its provisions in $\$ 113 .{ }^{183}$ It does not explain when the various enforcement options should be used. In theory, any violation that meets the minimal mental state required for a knowing violation could lead to civil or criminal prosecution, or both. The use of the CAA's criminal provisions is largely dependent on the exercise of prosecutorial discretion.

The exercise of the power to bring a criminal action should be based on (1) the significance of the adverse environmental impact or the extent of harm to the public's health; (2) the deceptiveness of the conduct; (3) the extent to which the defendant flouted the law; and (4) the repetitiveness of the violations or other aggravating factors. ${ }^{184}$ Criminal prosecution should not be used for technical violations of complex environmental laws, but intentional harmful actions by corporate executives should result in their criminal prosecution. However, criminal prosecution of individuals for violation of the CAA's emission control requirements appears more random than principled.

\section{The I/M Program in Utah}

\section{A. Overview}

Although the pollution from individual mobile sources has declined, mobile source emissions are a leading cause of air pollution. ${ }^{185}$ The steady increase in the number of miles traveled nullifies some of the benefits of reduced vehicle emissions per mile that are driven by EPA's emissions requirements for new motor vehicles. ${ }^{186}$

181. Id.

182. Id.

183. 42 U.S.C. $\$ 7413$.

184. David Uhlmann, Prosecutorial Discretion and Environmental Crime, 45 ELR 10801 (Aug. 2015).

185. See generally Arnold W. Reitze Jr., Mobile Source Air Pollution Control, 6 EnVTL. LAW. 309 (2000).

186. Id.
In Utah, on-road sources are responsible for $36 \%$ of the statewide $\mathrm{CO}$ emissions, $33 \%$ of the $\mathrm{NO}_{\mathrm{x}}, 8 \%$ of the particulate matter smaller than 10 micrometers $\left(\mathrm{PM}_{10}\right)$, $17 \%$ of the particulate matter smaller than 2.5 micrometers $\left(\mathrm{PM}_{2.5}\right), 1 \%$ of the sulfur oxide $\left(\mathrm{SO}_{\mathrm{x}}\right)$, and $3 \%$ of the VOCs. ${ }^{187}$ Because much of the motor vehicle use is concentrated in the areas of the state that are designated as nonattainment, the percentage of the pollutants contributed in those areas by motor vehicles should be expected to be much higher. The impact of pollutant emissions on ambient air quality is exacerbated by the topography of the state, which helps create the atmospheric conditions that result in poor air quality, especially during the winter months. ${ }^{188}$

The I/M program is applicable to nonattainment areas that are not in compliance with the CAA for pollutants related to automotive emissions. ${ }^{189}$ In Utah, the $\mathrm{PM}_{2.5}$ nonattainment areas of primary concern are located along the Wasatch Front from Ogden to Salt Lake City to Provo, but part of Cache County is also a nonattainment area that extends into Franklin County, Idaho. ${ }^{190}$ On April 28, 2017, EPA classified the Provo and Salt Lake City metropolitan areas as well as Davis and Weber Counties and parts of Box Elder and Toole Counties as serious PM $_{2.5}$ nonattainment areas, which will require a modified SIP be submitted to EPA. ${ }^{191}$ Salt Lake and Utah Counties are also nonattainment for $\mathrm{PM}_{10} \cdot{ }^{192}$ Salt Lake County and East Tooele County above 5,400 feet are nonattainment for sulfur dioxide $\left(\mathrm{SO}_{2}\right)^{193}$

If a nonattainment area achieves compliance with NAAQS, it must develop and implement a 10 -year maintenance plan that must be approved by EPA. ${ }^{194}$ In 1997 , pursuant to CAA $\$ 107(\mathrm{~d})(3)(\mathrm{E})$, EPA designated Salt Lake and Davis Counties as having attained the $\mathrm{O}_{3}$ standard, and it approved a maintenance plan, but that status may soon be changed to nonattainment. ${ }^{195}$ Davis County, Salt Lake County, and portions of Duchesne, Tooele, Uintah, Utah, and Weber Counties failed to meet the

187. Utah Division of Air Quality, 2015 Annual Report 23-25 (2016). VOCs from motor vehicles are an important source of anthropogenic emissions, but in Utah, biogenic sources release $74 \%$ of the VOCs. Id. at 25.

188. Arnold W. Reitze Jr., Utah's Fine Particulate Air Pollution Control Program, 2014 UtAh L. Rev. Online 113 (2014), available at https://papers.ssrn. com/sol3/cf_dev/AbsByAuth.cfm?per_id=361683.

189. CAA $\$ \$ 181(\mathrm{a})(2)(\mathrm{B}),(\mathrm{b})(4),(\mathrm{c})(3), 187(\mathrm{a})(4) \&(6), 42$ U.S.C. $\$ \$ 7511 \mathrm{a}(\mathrm{a})$ (2)(B), (b)(4), (c) (3), 7512a(4) \& (6).

190. Utah Division of Air Quality, supra note 187. Part of Cache, Box Elder, Weber, Tooele, and all of Davis, Salt Lake, and Utah Counties are nonattainment for $\mathrm{PM}_{2.5}$

191. Emma Penrod, EPA: Unmet Air-Pollution Standards Now "Serious," SAlt Lake Trib., May 3, 2017, at B1; Emma Penrod, Utah Air Quality Failures to Get "Serious" Status, Salt LaKe Trib., Dec. 17, 2016, at A1.

192. Id.

193. Utah Division of Air Quality, supra note 187, at 6.

194. CAA $\$ 175$ A, 42 U.S.C. $\$ 7505$ a.

195. Approval and Promulgation of Air Quality Implementation Plans; State of Utah; Salt Lake and Davis Counties Ozone Redesignation to Attainment, Designation of Areas for Air Quality Planning Purposes, Approval of Related Elements, Approval of Partial NO RACT Exemption, and Approval of Weber County I/M Program, 62 Fed. Reg. 38213 (July 17, 1997). See also 62 Fed. Reg. 28396 (May 23, 1997). But see Emma Penrod, Utah's 2017 Resolution: A Plan for Cleaner Air, Salt Lake Trib., Jan. 16, 2017, at A1. 
more stringent $2015 \mathrm{O}_{3}$ NAAQS. ${ }^{196}$ Utah's Department of Environmental Quality (DEQ) proposed designating three nonattainment areas for $\mathrm{O}_{3}{ }^{197}$ The Wasatch Front has also had problems with $\mathrm{CO}$ emissions that led to I/M program requirements. ${ }^{198}$

The I/M provisions are found in the Utah SIP, $₫ X$, Vehicle Inspection and Maintenance Program. ${ }^{199}$ Part A includes the general requirements; Part B covers Davis County; Part C covers Salt Lake County; Part D covers Utah County; Part E covers Weber County; and Part F applies to Cache County. ${ }^{200}$ However, Utah delegates implementation to the health department of nonattainment counties, as discussed below. ${ }^{201}$ The I/M program is designed to meet the CAA's specific requirements applicable to nonattainment areas, but it is also utilized as a control measure to attain and maintain the particulate NAAQS for $\mathrm{PM}_{2.5}$ and $\mathrm{PM}_{10}$ in Cache, Davis, Salt Lake, Utah, and Weber Counties. ${ }^{202}$

In 2015, EPA approved amendments to Utah's SIP that modified the general requirements of Utah's I/M program and approved the addition of $₫ X$, Part $F$ to add an I/M program for Cache County. ${ }^{203}$ The I/M program is countywide, although only part of the county is nonattainment for $\mathrm{PM}_{2.5}$. The I/M program in Cache County is not mandated by the CAA, but has been adopted by Utah as part of its attainment demonstration for Cache County in order to reduce $\mathrm{PM}_{2.5}$ precursor emissions of $\mathrm{NO}$ and VOCs. ${ }^{204}$

There is a separate I/M program for diesel-powered vehicles. On July 12, 1995, the Utah Air Quality Board adopted a diesel I/M program. ${ }^{205}$ Appendix 2 of $\$ X X I$ is applicable to Davis County; Appendix 3 is applicable to Salt Lake County; and Appendix 4 applies to Utah Coun-

196. Emma Penrod, Ozone: Utah Seeks Fed's Help, Salt LaKe Trib., Oct. 18, 2016, at A1.

197. Id. See also Penrod, Utah Air Quality Failures to Get "Serious" Status, supra note 191, at A4. The nonattainment areas are Western Utah County; Salt Lake and Davis Counties, the western portion of Weber County, and the more populated area of Toole County; and parts of Duchesne and Uintah Counties.

198. Salt Lake City has been redesignated as being in attainment for the CO standard and became CO maintenance areas. In 2005, EPA approved a revised CO maintenance plan and a revised I/M program for Salt Lake City. Provo was redesignated as attainment in 2005, and the I/M program for Utah County was approved. Ogden, which was redesignated as attainment for CO in 2001, had its maintenance plan revised on Sept. 14, 2005, in an EPA approval that also included the approval of the revised I/M program for Weber County. Approval and Promulgation of Air Quality Implementation Plans; State of Utah; Ogden City Revised Carbon Monoxide Maintenance Plan and Approval of Related Revisions, 70 Fed. Reg. 54267 (Sept. 14, 2005).

199. Utah Admin. Code R307-110-31 (2016), Vehicle Inspection and Maintenance Program.

200. Id.

201. See, e.g., Salt Lake County Health Department, Health Regulation \#22a, Vehicle Inspection/Maintenance.

202. Utah SIP, $₫$ X, Vehicle Inspection and Maintenance Program (adopted by the Utah Air Quality Board Dec. 5, 2012).

203. Approval and Promulgation of Air Quality Implementation Plans; State of Utah; Motor Vehicle Inspection and Maintenance and Associated Revisions, 204. Id. 80 Fed. Reg. 54237 (Sept. 9, 2015).

205. Utah SIP, $₫ X X I$, Diesel Inspection and Maintenance Program (July 12, 1995). ty. ${ }^{206}$ Utah County, however, ended its diesel I/M program in 2006. ${ }^{207}$ This program was developed to control $\mathrm{PM}_{10}$ emissions. Heavy-duty and light-duty diesel vehicles must meet opacity standards specified in Appendix 5 of SIP \$XXI. Light-duty diesel vehicles must meet cutpoints, or allowable emissions, designed to achieve a $10 \%$ reduction in diesel particulates. ${ }^{208}$ Violations may result in a penalty of $\$ 299$ per violation pursuant to Utah Administrative Code Rule R307-4. ${ }^{209}$

Each of the counties has implementing ordinances. There are data that indicate that diesel vehicles fail I/M inspections more often than gasoline-powered vehicles. Salt Lake County fails about $6 \%$ of the diesel vehicles; about one-half the failures are because the emissions systems have been deliberately disabled. ${ }^{210}$ In Morgan and Weber Counties about $4.5 \%$ of the gasoline vehicles fail, but $15 \%$ percent of the diesel vehicles fail, with about $40 \%$ of the failed vehicles showing evidence of tampering. ${ }^{211}$ In Weber County, however, the diesel I/M program only began on January 1, 2017, and there is one waiver for any vehicle failing the test in 2017 or $2018 .^{212}$

\section{B. Implementation of I/M in Utah}

Utah's I/M programs are health-based programs that are administered by local health departments. ${ }^{213}$ Counties with I/M programs may use standardized computerized I/M testing equipment, adopt standardized emission standards, and provide for reciprocity. ${ }^{214}$ Utah's basic I/M program is based on EPA's amended I/M regulations. ${ }^{215}$ Since 2002, $\mathrm{OBD}$ checks and OBD-related repairs are required as a routine component of Utah I/M programs on MY 1996 and newer LDVs and LDTs equipped with certified OBD systems. ${ }^{216}$ The federal performance standard requires repair of malfunctions or system deterioration identified by or affecting OBD systems. ${ }^{217}$

Utah's I/M programs are funded through several mechanisms including, but not limited to, a fee collected at the time of registration by the Utah Tax Commission Division of Motor Vehicles or the county assessor's office, which is remitted to the county in which the vehicle is

206. Id.

207. Emma Penrod, Emissions Testing That Targets Utah County Is Near Passage, Salt Lake Trib., Mar. 3, 2017, at A5.

208. Utah SIP, supra note 205, \$XXI.

209. Id.

210. Penrod, supra note 207.

211. Id.

212. Weber Morgan Health Department, Weber County I/M Bulletin (Nov. 7 , 2016), available at http://www.webermorganhealth.org/environmentalhealth/pdf/IM\%20Bulletin\%20diesel.pdf.

213. The authority is found at UtAH Code \$41-6a-1642 (2017). Davis and Salt Lake Counties started their I/M programs in 1984, followed by Utah County in 1986, and Weber County in 1990. 62 Fed. Reg. 38213-02 (July 17, 1997).

214. UTAн Code $\$ 41-6 a-1643$ (2005).

215. Amendments to Vehicle Inspection Maintenance Program Requirements Incorporating the Onboard Diagnostic Check, 66 Fed. Reg. 18156 (Apr. 5, 2001).

216. CAA $\$ 202(\mathrm{~m})(3), 42$ U.S.C. $\$ 7521(\mathrm{~m})(3)$.

217. Id. 
registered. ${ }^{218}$ The collection of fees for various permitting activities and the selling of inspection certificates to inspection stations are the other funding mechanisms. ${ }^{219}$

In 1994, the legislature provided that counties are to give preference to decentralized testing facilities and to use the most cost-effective means to achieve and maintain the maximum benefit with regard to air quality standards and to meet federal air quality requirements related to motor vehicles. ${ }^{220}$ This has resulted in Utah having only decentralized test-and-repair facilities.

In 2002, Utah's statute was amended to allow for inspections every other year for vehicles that are six years old or newer on January 1 each year. ${ }^{221}$ Therefore, vehicles less than two years old on January 1 of any year are exempt from an I/M inspection. In 2005, the legislature allowed counties with an I/M program to require college students and employees who park a motor vehicle on a college or university campus that is not registered in a county subject to emission inspection to provide proof of compliance with an emission inspection. ${ }^{222}$ Only Cache County requires compliance by college students. ${ }^{223}$

\section{Salt Lake County's Program}

As previously discussed, Utah's air pollution control program is based on a revised SIP that includes a vehicle inspection program in its $\$ X$. The section has subdivisions applicable to the counties subject to an I/M requirement. ${ }^{224}$ County health departments have promulgated additional I/M regulations because implementation of the I/M program has been delegated to the counties. The I/M program is therefore a mix of federal, state, and local law. The Salt Lake County Health Department's regulation \#22, Vehicle Emissions Control Program, is authorized by the Utah Code and is typical of the approach used in other counties in Utah. ${ }^{225}$

Salt Lake County implements the I/M program using more than 400 vehicle inspection stations. ${ }^{226}$ The county's regulation applies to owners of motor vehicles in Salt Lake County; publicly owned vehicles operated in the county; owners, operators, and managers of I/M stations; and $\mathrm{I} / \mathrm{M}$ inspectors and suppliers of analyzer equipment and gas calibrations. ${ }^{227}$ Analyzers include the OBD scanner. ${ }^{228}$ Gaseous or liquid petroleum-powered vehicles of MY 1968 or newer; light- and medium-duty diesel-powered vehicles

218. 62 Fed. Reg. 38213-02 (July 17, 1997). Utah Code \$41-6a-1642(10) (2016).

219. 62 Fed. Reg. 38213-02 (July 17, 1997).

220. UTAH Code $\$ 41-6 a-1642(2)$ (c) (2016).

221. Id. at $\$ 41-6 a-1642(6)$ (b) (2002).

222. Id. \$41-6a-1642(5) (2005).

223. Bear River Health Department, Regulation No. 2013-1, \$6.3.

224. See supra note 202-03 and accompanying text.

225. Utah Code $\$ 26 A-1-114$ (2016).

226. Applus Automotive, Success Stories: Salt Lake \& Weber County Utah Vehicle-Emissions Testing Programmes, http://www.applusautomotive.com/ en/successStory/Salt_Lake_\&_Weber_County_Utah_vehicle-emissions_ testing_programmes-1340209435611 (last visited Aug. 3, 2017).

227. Salt Lake County Health Department, Health Regulation \#22, \$1.1.

228. Id. $\$ 2.4$. of MY 1998 and newer; and specified heavy-duty dieselpowered vehicles are required to pass an I/M inspection. ${ }^{229}$ Vehicles six years and older must be inspected annually; newer vehicles are inspected every other year. ${ }^{230}$

The inspection measures the emissions of $\mathrm{HC}$ and $\mathrm{CO}$ based on a two-speed idle test (TSI), opacity and/or an OBD II test, as well as a visual inspection of the emission control systems. ${ }^{231}$ The cutpoints are based on the weight, class, and MY of the vehicle and are found in Appendix $\mathrm{C}$ of the regulation. ${ }^{232}$ TSI inspections are required for MY 1968-1995 light-duty, non-diesel vehicles and for MY 1968 and newer medium-duty and heavy-duty non-diesel vehicles. ${ }^{233}$ Non-diesel vehicles of MY 1996 and newer and MY 1998 and newer light-duty and medium-duty diesel vehicles are subject to OBD inspections and a visual tampering inspection. ${ }^{234}$ There are separate $\mathrm{I} / \mathrm{M}$ provisions for heavy-duty diesel vehicles that are applicable only in Salt Lake County. ${ }^{235}$

If a vehicle fails an I/M inspection and the failure cannot be repaired for a specified cost (\$450 for 1996 and newer non-diesel vehicles), it may be eligible for a waiver. ${ }^{236}$ Violators of the I/M regulation are subject to criminal, civil, and administrative enforcement actions. ${ }^{237}$ Most I/M violations are a Class B misdemeanor pursuant to Utah Code Annotated $\$ 26 \mathrm{~A}-\mathrm{a}-123 .{ }^{238} \mathrm{~A}$ penalty schedule is found in the regulation's Appendix B. ${ }^{239}$

In Salt Lake County, I/M inspections increased from 437,888 in 2006 to 686,672 in 2015 , with 532,526 performed in the first nine months of 2016. ${ }^{240}$ The I/M inspections are based on testing the OBD system for newer cars while older vehicles without an OBD system are subject to a TSI test. ${ }^{241}$ As new vehicles replace old vehicles, the percentage of tests based on the OBD system increases, and in $2015,87.26 \%$ of the tests only involved OBD testing. The failure rate for the I/M test was $4.6 \%$ in 2015 and $4.11 \%$ in the first nine months of 2016. ${ }^{242}$

Assuming the average cost of an I/M test for vehicle owners is $\$ 25$, the cost to Salt Lake County vehicle owners in 2015 was $\$ 17,166,800$. Since 31,609 vehicles failed the test, simple arithmetic demonstrates the cost for each vehicle that fails the I/M test is more than \$543. If we assume it takes an hour to have a vehicle tested and the driver's time is worth $\$ 15$ an hour, the additional cost to Salt Lake County residents in 2015 was $\$ 10,299,780$ (686,652 mul-

\footnotetext{
229. Id. $\$ 4.1 .8$. Certain vehicles are exempted by $\$ 4.1 .7$.

230. UTAH Code \$41-6-163(6) (2016).

231. Salt Lake County Health Department, Health Regulation \#22, $\$ \$ 2.36$, 2.58. OBD is defined at $\$ 2.47$.

232. Id. $\$ \$ 2.17,4.1 .4$.

233. Id. app. A $\$ 3.2 .3$.

234. Id. app. A $\$ 3.2 .3(3)$.

235. Id. app. D.

236. Id. $\$ 4.4$.

237. Id. $\$ 7$.

238. Id. $\$ 8.1$.

239. Id. app. D.

240. Data supplied to the author by Ed C. Jensen, an air pollution control specialist with the Salt Lake County Health Department, Sept. 23, 2016. 241. Salt Lake County Health Department, Health Regulation \#22, \$2.36. 242. See supra note 240.
} 
tiplied by $\$ 15)$. The total cost is more than $\$ 27$ million, or about $\$ 869$ per vehicle failed. This does not include the cost of repairing failed vehicles, but that information is unavailable. It also does not include the cost of administering and enforcing the I/M program. Is the program worth the cost?

\section{Evaluating the I/M Program}

One of the issues surrounding the I/M program in Utah, and throughout the country, is the inability to calculate the effectiveness of the I/M programs. As this Article has demonstrated, the I/M program has had minimal effectiveness in detecting and/or dealing with the failures of manufacturers to build vehicles that continue to meet federal emission requirements. The value of this program therefore depends on its ability to reduce emissions from in-use vehicles.

In the early days of the I/M program, it was easier to estimate the tons of pollutants reduced because emissions were measured during the I/M test. After OBD became nearly universally installed in U.S. vehicles, emissions generally are not tested, and even if they are, it is unlikely that they would be excessive compared to vehicles manufactured in the past. Moreover, in states similar to Utah, where only five counties have I/M programs, some residents may register their vehicles in a county that does not require an I/M inspection.

In 1997, when EPA approved Utah's I/M program, it had to make a judgment that the program would help the state meet its CAA obligations. ${ }^{243}$ This could have included a quantification of the expected benefits, but it did not. The legal requirements for Utah's SIP included an emissions inventory that showed total emissions were less than or equal to the 1994 emissions. Thus, the emissions for point sources, area sources, on-road mobile sources with I/M programs in place, and nonroad sources were aggregated. Emissions without I/M were not calculated, which means the reduction benefits of I/M could not be determined, but Utah did model on-road benefits of enhanced I/M over basic I/M. ${ }^{244}$

Although there have been many updates to the I/M program, there has not been any new quantification of the emissions reductions attributable to the program. However, in 2015, Utah's Division of Air Quality used EPA's

243. Proposed Approval and Promulgation of Air Quality Improvement Plans; State of Utah; Salt Lake and Davis Counties Ozone Redesignation to Attainment, Designation of Areas for Air Quality Planning Purposes, Proposed Approval of Related Elements, Proposal Approval of Partial NO, RACT Exemption, and Proposed Approval of Weber County I/M Program, 62 Fed. Reg. 28396 (May 23, 1997).

244. Letter from Timothy Russ, Environmental Scientist, EPA Region 8, to the author (Nov. 9, 2016). More details can be found at Proposed Approval and Promulgation of Air Quality Implementation Plans; State of Utah; Salt Lake and Davis Counties Ozone Redesignation to Attainment, Designation of Areas for Air Quality Planning Purposes, Proposed Approval of Related Elements, Proposed Approval of Partial NO RACT Exemption and Approval of Weber County I/M Program, 62 Fed. Reg. 28396 (May 23, 1997). The proposal showed reductions in VOC emissions in tons per day from 75.40 in 1994 to 56.47 in 2007 and reductions in $\mathrm{NO}_{\mathrm{x}}$ from 73.66 to 67.31. These reductions assumed the use of I/M. Id. at 28405. approved on-road emissions model, MOVES2014a, to estimate the emissions reduction from on-road vehicles. ${ }^{245}$ It estimated that the $\mathrm{I} / \mathrm{M}$ program resulted in emissions reductions in Salt Lake County of 9,354 tons per year (tpy) for CO, 851 tpy for $\mathrm{NO}_{\mathrm{x}}$, and 653 tpy for VOCs. ${ }^{246}$ Because the pollutants of interest to the state are primarily $\mathrm{NO}_{x}$ and VOCs, the cost of the I/M program divided by the reductions in these pollutants results in a crude cost estimate of nearly $\$ 18,000$ per ton. ${ }^{247}$ The cost is higher if we include the cost of repairing the failed vehicles, but that information is unavailable. Additional costs are incurred to administer and enforce the I/M program.

For comparison, EPA's 2016 Cross-State Air Pollution Update for the 2008 Ozone NAAQS determined that the estimated marginal cost of $\$ 1,400$ per ton for the control of electric power-generated $\mathrm{NO}$ is a cost-effective control strategy. ${ }^{248}$ In its $2013 \mathrm{PM}_{2.5}$ SIP, the Utah DEQ estimated the costs to reduce 2017 emissions in the Salt Lake area by 43.1 tons per day. ${ }^{249}$ Area source controls were expected to cost between $\$ 238$ and $\$ 6,560$ per ton of reduction. ${ }^{250}$ On May 23, 2017, Utah's Division of Air Quality proposed new VOC controls for eight area sources encaged in coating operations as part of its upcoming serious $\mathrm{PM}_{2.5}$ SIP revision. The staff analysis found the cost of removing a ton of VOC ranged from $\$ 1,878$ to $\$ 3,658$, with an average cost of $\$ 2,596 .{ }^{251}$ Point sources are required to install controls at a cost of $\$ 1,357$ to $\$ 23,319$ per ton of reduction..$^{252}$ As an example of the high costs of compliance, when the Holly refinery upgraded its facility in 2013, it estimated the cost per ton of emissions from its flare gas recovery system at $\$ 141,082.07$ per ton for $\mathrm{NO}_{\mathrm{x}}$ and $\$ 151,494.03$ per ton of VOC reduction. ${ }^{253}$

Thus, I/M costs, although significantly higher than most area source controls, when compared to other stationary source compliance costs, are not the only sources to have high costs imposed. After a half-century of effort to control air emissions, additional emissions reductions are often costly. However, the benefits of the I/M program are not well-documented.

The cost per ton of emissions reduction due to I/M programs can be quantified, but the effort involves making assumptions that will affect the result. However, because the emissions reductions from I/M are largely unknown, benefits are difficult to quantify. I/M may help force the

245. Letter from Richard McKeague III, Transportation Planner/Air Quality 246. Id.

Modeler, Utah Division of Air Quality, to the author (Oct. 31, 2016).

247. Id.

248. 81 Fed. Reg. 74504, 74508 (Oct. 26, 2016).

249. Information Sheet, Utah DEQ Division of Air Quality, $\mathrm{PM}_{2.5}$ State Implementation Plan (SIP): Salt Lake and Provo SIPs (Sept. 2013).

250. Id.

251. Memorandum to the Air Quality Board (May 23, 2017) (on file with author).

252. Information Sheet, Utah DEQ, supra note 249.

253. Letter from Holly Refinery \& Marketing Co.-Woods Cross LLC, to Bryce Bird, Director, Utah DEQ Division of Air Quality (Mar. 21, 2013) (Revised Netting Analysis for the Heavy Crude (Black Wax) Processing Change to the Modernization Project), available at https:// deq.utah.gov/businesses/H/hollyrefinery/crudeproject/docs/2013/jun 2013/SupplementalNOIs32113to43013.pdf. 
public to confront the impact their vehicles have on mobile source air pollution, which is the major source of air pollutants in most nonattainment areas. To the extent this motivates behavior, the I/M program may result in better maintenance of vehicles, but this possible benefit is not quantifiable. The nature of the $\mathrm{OBD}$ check is to detect vehicle malfunctions early and have them remedied, thus preventing emissions, but this also is not easily quantified. In addition, drivers may voluntarily seek repairs prior to an I/M inspection if their vehicle's MIL indicates emissions problems, which can result in emissions reductions long before a vehicle is scheduled for I/M.

Even if state or local governments conclude that the benefits of I/M do not exceed the costs, to avoid having an I/M program may be difficult because the CAA requires it in areas with serious air pollution problems. Moreover, even if the CAA does not require I/M, the states, including Utah, may voluntarily choose to adopt an I/M program in order to obtain emission reduction credit that is needed to demonstrate reasonable progress toward meeting ambient air quality targets. The I/M requirements represent a policy that is based on the conditions of the 1970s, when cheating was rampant and tampering was easy. Today, emission control technology is far more sophisticated and tampering is more difficult. At this time, there is little current information to either support or reject the efficacy of the I/M program.

Environmental law is becoming more focused on the cost of regulations. On June 29, 2015, the U.S. Supreme Court held that EPA "must consider cost-including, most importantly, cost of compliance-before deciding whether regulation is appropriate and necessary." ${ }^{254}$ The case involved the mercury and air toxic standards that were being imposed on the power industry. ${ }^{255}$ The Court held that EPA erred when it failed to consider the costs of the regulation in making its initial determination that the rule was appropriate and necessary. After remand, the D.C. Circuit sent the rule back to EPA, and the Agency decided the rule was necessary and appropriate even when costs were taken into consideration. ${ }^{256}$ While the case can be distinguished from the I/M program, it does indicate that EPA should seriously consider costs and must consider them early in the regulatory process. It could be useful to take a fresh look at the costs and benefits of the I/M program. Such knowledge could result in a more effective program.
254. Michigan v. Environmental Prot. Agency, 135 S. Ct. 2699, 45 ELR 20124 (2015).

255. Patrick Ambrosio, Alternative Compliance Rule for Mercury, Air Toxics Challenged by Utility Industry, 46 Env't Rep. (BNA) 561 (Feb. 27, 2015); Stuart Parker, Utilities Say EPA Violated Air Law in Revisions to MACT's SSM Provisions, 26 Clean Air Rep. (Inside EPA) 5:25 (Feb. 26, 2015).

256. Stuart Parker, High Court Denies Utility MACT Suit but Further Appeal Remains Possible, 27 Clean Air Rep. (Inside EPA) 12:3 (June 16, 2016). 